RECENZJE - POLEMIKI

\section{(c) (i) $\odot$}

http://dx.doi.org/10.12775/AE.2020.027
ARCHIWUM EMIGRACJI

Studia - Szkice - Dokumenty

Toruń, Rok 2020, Zeszyt 28

\title{
„On kochał Polskę”, czyli jak nie należy wydawać zbiorów listów
}

\begin{abstract}
„On kochat Polske”. Listy Stanisława Szukalskiego do Mariana Konarskiego z lat 1950-1987, opracował, wstępem i przypisami opatrzył Tadeusz Zych, Tarnobrzeg 2019, s. 854; recenzent: Lechosław Lameński.
\end{abstract}

Obszerny, liczący 854 strony, tom listów Stanisława Szukalskiego do Mariana Konarskiego jest lekturą niezwykłą. Pozwala bowiem zrozumieć bardzo trudną sytuację polskiego artysty egzystującego w emigracyjnym osamotnieniu, pozbawionego (głównie z powodów finansowych) możliwości swobodnego tworzenia, żyjącego bez kontaktów $\mathrm{z}$ innymi, nie tylko rodzimymi, twórcami i odbiorcami, a dodatkowo niewidzącego szansy na powrót do ojczyzny — i to z dwóch powodów. Po pierwsze, Szukalski uważał, że Polska po II wojnie światowej ,jest [...] prywatną własnością Rosji” (s. 393). A po drugie nieustannie oskarżał ojczyznę i rodaków o zaniedbanie swojego talentu, twierdził, że nie stworzyli mu odpowiednich warunków do pracy twórczej. Ten niezwykle skomplikowany stosunek Szukalskiego do ojczyzny wymaga z pewnością zbadania i odrębnego omówienia.

Dodać tu jednak należy, że sytuacja Szukalskiego nie miała charakteru niepowtarzalnego, unikatowego. Jego los dzielili inni emigranci, wśród nich np. Józef Mackiewicz czy Leo Lipski, którzy egzystowali w jeszcze trudniejszych warunkach. Tym jednak, co odróżniało go od nich, była przyczyna opuszczenia kraju. Emigracja niepodległościowa, rekrutująca się w dużej mierze z byłych żołnierzy armii Andersa, stawiała sobie za cel wyrwanie Polski spod wpływów sowieckich, co sprawiło, że miała ona charakter polityczny. Szukalski opuścił ojczyznę z pobudek artystycznych — nie mogąc w pełni rozwinąć w niej swojego talentu poszukiwał szansy (jak się okazało, w dużym stopniu nieskutecznie) w Stanach Zjednoczonych.

Omawiany tom listów pozwala czytelnikowi wniknąć i choćby częściowo rozpoznać tragiczny los jednostki wybitnej, osobowości wyjątkowej, która nie radzi sobie w zmaganiach z własnymi demonami, objawiającymi się m.in. pod postaciami zastygłego w przedwojennej formie antysemityzmu i żarliwego, podsycanego umiłowaniem prasłowiańskich wierzeń antyklerykalizmu i antykatolicyzmu. Widzimy, jak Szukalski siłuje się z samym sobą, z Polską, którą deklaratywnie odrzuca, ale bez której nie może żyć, ze współczesną mu kulturą, która w jego przekonaniu jest hochsztaplerką, z upływającym czasem i własną przeszłością. Widzimy, jak pozbawiony możliwości podej- 
mowania działań artystycznych, wykorzystuje twórczą energię na realizację wieloletniego paranaukowego projektu, w którym formułuje tezy tyleż śmiałe, co absurdalne. Przekonany o słuszności obranego kierunku, jak i uzyskanych rezultatów („cudów dokonałem [...] gigantyczne dzieło stworzyłem”, s. 311), negujący fakty naukowe, zamykający się z dnia na dzień na świat, staje się coraz bardziej samotny, rozgoryczony, zgorzkniały. Co ciekawe, do końca nie traci nadziei na poprawę swojego losu list ostatni, z 19 lutego 1987 r., kończy myślą: „Poczekam jeszcze kilka miesięcy, a jeżeli NIC się mi nie przydarzy, to przeniosę się do Francji i tam powiększę [...] me możliwości...".

W tym ujęciu tom listów Stanisława Szukalskiego do Mariana Konarskiego „,On kochat Polskę" jest niezwykle interesującą poznawczo i — co cenne - angażującą emocjonalnie lekturą. Jako taki zasługuje $\mathrm{z}$ pewnością na uwagę. Problem polega jednak na tym, że jakkolwiek publikacja ta ma w założeniach charakter naukowy (zbiór korespondencji został opatrzony przypisami, obszernym wstępem, notą edytorską, indeksem nazwisk), to jednak — co należy wyraźnie zaznaczyć — nie spełnia ona kryteriów, jakie takim edycjom się stawia.

Książkę opracował Tadeusz Zych, historyk, prezes Tarnobrzeskiego Towarzystwa Historycznego oraz redaktor naczelny „Tarnobrzeskich Zeszytów Historycznych”, a także Dyrektor Muzeum Historycznego Miasta Tarnobrzega, która to instytucja jest także wydawcą tomu. Autorski wkład w książkę (pomijając edycję i przypisy), to m.in. Wstęp oraz Nota edytorska. Już lektura obu tych części budzi szereg zastrzeżeń i dodajmy — osłabia wolę lektury całości tomu. Zawartość Wstępu wskazuje, że oto mamy do czynienia z pamiątkowym pomnikiem tworzonym przez już nawet nie gorącego miłośnika, lecz zgoła wyznawcę Szukalskiego. Oczywiście emocjonalny stosunek do tzw. przedmiotu badań nie jest wadą, ale kontrolowanie poziomu dzielenia się nim z czytelnikiem stanowi spore wyzwanie.

Afektywny stosunek autora edycji do Szukalskiego widać m.in. w przejęciu od członków założonej przez niego w 1929 roku grupy artystycznej Szczep Rogate Serce nomenklatury „mistrz” i relacji „mistrz - uczeń” (m.in. s. 13, 14, 15, 19, 21, 22, 39). Nie ma oczywiście niczego złego w cytowaniu tych zwrotów, ale już pisanie bezpośrednio o Szukalskim „mistrz” musi zmuszać do postawienia pytania o stosunek opracowującego do epistolografa. Takich sygnałów w początkowych częściach książki jest więcej. Tadeusz Zych ujawnia swój stosunek poprzez dobór słów czy formułowane oceny. Przykłady można mnożyć, ograniczmy się do kilku (podkreślenia moje; miejsca w których pojawiają się błędy lub niefortunne sformułowania w całej recenzji oznaczono [!]): „niezasłużenie dźwigając do końca życia «znamię» faszysty” (s. 17); „Pomimo tego żyje marzeniami, w tym przede wszystkim artystycznymi, które nie tyle trzymają go przy życiu, co nadają tej egzystencji sens” (s. 18); „Niestety ani tego, ani też wielu innych pomysłów nie udało mu się nigdy zrealizować” (s. 18); „istniejące poglądy dotyczące Szukalskiego w dalszym ciągu kształtowane są przez stereotypy" (s. 20); „tak zaciekłość krytyki, która chciała go zdyskredytować, jak i, co gorsza, zmowy [!] milczenia, jaka spotkała jego i jego twórczość” (s. 26), „Nielatwo spotkać na kartach polskich epistolografii czy literatury strof [!] o takiej sile i tak głębokich, dotyczących tęsknoty za utraconą ojczyzną [...]" (s. 27 - tu należy zaznaczyć, że zawarta w tym zdaniu teza nie jest prawdziwa); „W ten oto sposób spotkały się dwa swoiste stereotypy, jeden o Szukalskim antysemicie [...]" (s. 37). Rozumiem intencje autora Wstępu i chęć zdjęcia z Szukalskiego ciążącego nad nim odium, ale problem polega na tym, że taki sposób pisania odbiega od standardu akademickiego obiektywizmu. Szkoda, że autor nie pozostawił oceny Szukalskiego tym, którzy zechcą 
się z jego listami zapoznać i nie napisał Wstępu z dbałością o zachowanie większego dystansu do „obiektu badań”.

Wstęp budzi zastrzeżenia także $\mathrm{w}$ zakresie napięcia między tekstem naukowym a popularyzatorskim. W tę drugą stronę ciążą zdania ogólne, które nie pozwalają czytelnikowi odnieść się do meritum, a jedynie zawierzyć autorowi. Tak jest np. z opisem reakcji krytyki na wystawy: „Recenzje są dla młodego artysty więcej niż pozytywne” (s. 10); „Po wszystkich, recenzje były różne; od zachwytów po ostrą krytykę” (s. 13), czy stwierdzeniem, że Glenn Brayer i Lena Zwalve ,sprawili, iż cały jego dorobek został zarchiwizowany oraz udało się wydać dwa albumy prac Szukalskiego i zamieścić [!] kilka artykułów na jego temat" (s. 19). Te stwierdzenia, pozbawione rozwinięcia w formie przykładowych cytatów lub wymienienia kilku krytyków bądź to doceniających prace artystyczne, bądź też odmawiających im wartości, bez podania w przypisach informacji bibliograficznych na temat tych dwóch albumów i kilku (ilu?) artykułów niewiele wnoszą do rozpoznania tematu i osłabiają naukowy charakter Wstęu.

Pomijając warstwę językową Wstępu warto skupić się przez chwilę na jego zawartości merytorycznej. Został on podzielony na trzy części. W pierwszej przedstawiono biografię Szukalskiego, w drugiej Mariana Konarskiego (jednego z członków grupy artystycznej Szczep Rogate Serce). Część trzecia poświęcona jest problematyce listów zebranych w tomie. Autor opracowania wskazał tu na „tematy, które nieustannie się powtarzają, do których wracał przez cały okres trwania korespondencji” (s. 24). Wyróżnione zagadnienia to: Sztuka, Szczep Rogate Serce, Polska, Kościół, Jan Paweł II, Żydzi. I o ile w odniesieniu do dwóch pierwszych nie sposób zgłosić zastrzeżeń, to tyle trzy kolejne nie wydają się tak bardzo frapujące, czy zajmujące jak np. stosunek Szukalskiego do jego własnej twórczości lub jego paranaukowe zainteresowania i związane z nimi działania podejmowane przez wiele lat.

Znaczna część listów pisanych przez Szukalskiego skoncentrowana jest na nim samym. Na jego twórczości artystycznej, zabiegach o jej scalenie i ocalenie, na planach na przyszłość, także na braku możliwości tworzenia i wynikających z tego frustracji i poszukiwaniu winnych (to łączy się wyraźnie z wyróżnionym we Wstępie stosunkiem do Polski). Natomiast $\mathrm{w}$ odniesieniu do drugiego zagadnienia trzeba przypomnieć, że Szukalski pozbawiony po emigracji do USA możliwości uprawiania twórczości artystycznej, podjął nową aktywność, którą sam uważał za działalność naukową. Poszukiwał mianowicie dowodów na istnienie „Macimowy” (ang. Protong), która utożsamiana z pierwotną polszczyzną miała być źródłem wszystkich innych języków. Autor wstępu i opracowania słusznie dystansuje się od uznawania tego obszaru działalności Szukalskiego za naukową, opatrując to słowo cudzysłowem (s. 18), czy pisząc na s. 18, 19, 29 o aktywnościach „paranaukowych”. Szkoda jednak, że - między innymi ze względu na częstotliwość powracania tego tematu w korespondencji — nie zechciał go wyróżnić i omówić we wstępie. Czy były inne powody tej decyzji? Nie wiadomo, ale można odnieść wrażenie, że z jednej strony dobór tematów wyróżnionych, jak i tych, które zdaniem autora opracowania na to nie zasłużyły, jest dość znaczący.

Jak już bowiem wspomniano wcześniej, autor opracowania, Tadeusz Zych, zdradza wyraźnie daleko idącą fascynację postacią artysty. To — podkreślmy po raz kolejny nie błąd, o ile ta postawa nie waży na rzetelności badawczej. Tu natomiast mamy do czynienia z sytuacją, w której należy postawić pytanie o obiektywizm poznawczy i dystans badacza. Zestawiając Wstęp z treścią listów nie sposób się oprzeć wrażeniu, że o czym już wspomniano wcześniej - mamy tu do czynienia z próbą upamiętnienia Szukalskiego, nie zaś z rzetelną pracą badawczo-edytorską. Kontrowersyjność poglądów artysty, głównie jego antysemityzm, pełen urazy i pretensji stosunek do Polski, 
paranaukowe zapędy osiągające poziom groteski, wreszcie trudny charakter (skłonność do obrażania się, pieniactwa itp.) - wszystko to nie pasuje do monumentalnego portretu wielkiego twórcy. Czy zatem z tego powodu we Wstępie wyróżniono Kościół i Jana Pawła II (dodajmy, że i w tych obszarach poglądy Szukalskiego były wyraziste i nie zawsze świadczyły o pozytywnym stosunku zarówno do instytucji, jak i papieża)? Czy wyodrębnienie tych tematów wraz z wymownym tytułem całości zbioru („On kochał Polskę") ma służyć swoistej rehabilitacji Szukalskiego w oczach czytelnika? Niestety treść książki na to nie odpowiada, pozostaje nam zatem jedynie gubić się w domysłach...

Zresztą prezentacja najbardziej drażliwej kwestii w poglądach Szukalskiego opisana w ostatniej części Wstępu - także pozostawia nieco do życzenia. Autor Wstę$p u$ przyznaje wprost, że artysta był antysemitą (,Szukalski antysemitą niewątpliwie był, lecz warto prześledzić ten rodzaj antysemityzmu, który - dodajmy bez cienia wątpliwości - przez całe życie (nie zmieniło tego nawet doświadczenie Holokaustu) był jego udziałem.”, s. 35). To należy docenić. Jednocześnie, wykazując zrozumienie dla intencji pobudek autora $W s t e ̨ p u$, należy stwierdzić, że próby osłabienia tego zarzutu i zdjęcia odium z Szukalskiego, poszukiwanie usprawiedliwienia dla jego postaw i poglądów, jakie odnajdujemy we Wstepie (głównie na s. 36), nie są przekonujące. Próba dowodzenia, że Szukalski był antysemitą, bo krytycy z wydawanego w Warszawie w latach 1935-1939 miesięcznika „Arkady”, źle oceniali jego sztukę, jest niewiarygodne i co więcej niczego nie wyjaśnia. Co najwyżej pokazuje, jak niskimi pobudkami kierował się Szukalski. W tym obszarze, szczególnie w nim, dystans naukowca powinien pozwolić Tadeuszowi Zychowi zachować właściwe proporcje i umiar oraz oddalić od niego chęć dokonywania naukowej ekwilibrystyki, sięgania m.in. po hasła o stereotypach, porównywaniu antysemityzmu $\mathrm{z}$ antypolonizmem (po co w tym miejscu pojawiają się nawiązania do współczesności?). Zamiast tego znacznie lepsze byłoby uważne i oszczędne w słowach opisanie źródeł konfliktu, z wykazaniem dowodów (lub ich braku!) w postaci nazwisk negatywnie oceniających dokonania Szukalskiego krytyków i tytułów ich tekstów (tu z pomocą przychodzi sam artysta, wymieniając niektórych $\mathrm{z}$ nich $\mathrm{w}$ swoich listach). Rzecz jasna, nawet kompletne zestawienie nie wyjaśniałoby zapewne wszystkich przyczyn antysemityzmu Szukalskiego (uprzedzenia ze swej natury są trudne w badaniu). A już z pewnością nie pozwoliłoby na usprawiedliwienie tej postawy.

A co z podejmowanymi przez Szukalskiego wielokrotnie, powracającymi w korespondencji regularnie, uwagami dotyczącymi „Macimowy”? Trzeba tu oddać artyście, że jego zaangażowanie i poświęcenie dla sprawy było imponujące. Tysiące stron notatek, setki lektur obejmujących obszary od językoznawstwa po archeologię, od historii po astronomię, aktywność korespondencyjna i zabieganie o zainteresowanie opracowaną przez siebie koncepcją świata naukowego - wszystko to zdumiewa rozmachem, konsekwencją, skrupulatnością. Gdybyż jeszcze było osadzone na naukowych postawach, a nie życzeniowym stosunku do rzeczywistości... Czemu więc — powtórzmy pytanie — zostało tylko wspominane we Wstępie, nie zasłużyło na osobne omówienie? Być może dlatego, że ten obszar aktywności Szukalskiego jest obecnie bardzo mocno eksplorowany i wykorzystywany przez zwolenników i wyznawców paranaukowej teorii Wielkiej Lechii, którzy przyznają twórcy koncepcji „Macimowy” poczesne miejsce $\mathrm{w}$ gronie głosicieli polskiej supremacji. Kolejna cecha nie pasująca do portretu wielkiego artysty.

Jakkolwiek nie było, pominięcie tego wątku i próby odsunięcia w cień lub zracjonalizowania tych cech osobowości i składowych jego światopoglądu, które nie pasują 
do obrazu wybitnego artysty (którym Szukalski niewątpliwie był!), wraz z tytułowym zapewnieniem „On kochał Polskę” sprawiają że obraz wyłaniający się ze wstępu jest niepełny. Tu zresztą należy dodać, że sam Wstęp pozbawiony jest zakończenia, urywa się gwałtownie po części zatytułowanej Żydzi, po czym następuje Nota edytorska. I tu kolejne zaskoczenie, gdyż w opublikowanej formie Nota nie przynosi wielu podstawowych informacji o formie i sposobie opracowania listów, pozwala nam natomiast wejrzeć w... przemyślenia Tadeusza Zycha na temat tego, jakie znaczenie mają listy Szukalskiego i czemu jego admiratorzy po wojnie cierpieli na - jak to określił „listowstręt” (s. 41). Znacznie lepiej by się stało, gdyby te rozważania (s. 41-42) zostały przesunięte do Wstępu, mogłyby wówczas stanowić jego brakujące zakończenie, posumowanie.

Druga część Noty edytorskiej także pozostawia sporo do życzenia. Autor opracowania rozpoczyna od uwagi, w której stwierdza, że „Szukalski posługiwał się specyficzną polszczyzną, w sposób świadomy łamiąc zasady i kanony polskiej ortografii" (s. 42), po czym cytuje artystę, który wprost przyznaje się do braków w wykształceniu i wiąże je ze zmianą miejsca zamieszkania $\mathrm{w}$ dzieciństwie (,,[..] co wiedziałem przed pierwszym wyjazdem do Stanów, było kiedym miał jedenaście lat i nigdy się Polskiego języka nie uczyłem, zaś, co do gramatyki to jej nie znam boć nie miałem żadnego wykształcenia. Piszę tak jak mi się wydaje logicznem" (s. 42). Wobec takiego wyznania trudno raczej mówić o działaniu świadomym, a można jedynie o świadomości własnych braków. Rzecz jasna taki sposób pisania stanowi spore wyzwanie dla edytora, czego wydawca listów Szukalskiego jest świadomy. Problem polega jednak na tym, że — jak deklaruje — „Poprawiono jedynie ewidentne błędy ortograficzne” (s. 43). Co to znaczy? Czy „Polak” zapisany małą literą (s. 28) oraz przymiotnik „Polskiego” w przywołanym cytacie zapisany wielką literą, to są błędy nieewidentne? A jakiego typu błędami są przymiotniki „polskie” (s. 52), ,japońskie” (s. 57), „germańskie” (s. 57), „chińskie” (s. 59) zapisane wielką literą? Na marginesie wypada dodać, że przywołane przykłady to wierzchołek góry lodowej! Podobnie zaskakująca jest konstatacja mówiąca o tym, że „Część jego «błędów» [!] ortograficznych, wynikało z przyczyn technicznych, albowiem posługiwał się maszyną do pisania z czcionkami angielskimi. Jednak, kiedy uznał to za konieczne, dopisywał ołówkiem, bądź długopisem polskie znaki” (s. 42). Darmo w Nocie szukać informacji co z tego typu błędami (jakże znaczący cudzysłów!) poczynił opracowujący. Jeżeli dodać do tego, że „Starano się zachować oryginalną pisownię, w tym występujące, typowe zresztą dla stylu Szukalskiego anachronizmy." (s. 43), ustalenie, który fragment tekstu został poddany redakcji, a który nie praktycznie przestaje być możliwe.

Dodatkowo z Noty dowiadujemy się, że jakkolwiek większość spośród 168 listów zostało napisanych na maszynie, to jednak ,z częstym odręcznym uzupełnieniem, pod spodem kartki, bądź na jej marginesach" (s. 43). Myliłby się jednak ten, kto liczy na to, że stosowane adnotacje na ten temat zostały następnie poczynione przy kolejnych listach. Równie niewiele pożytku przynosi kolejna informacja, która brzmi: „W 25 przypadkach adresowane były do kilku osób, bądź do całego Szczepu” (s. 43).

Jak powszechnie wiadomo, edycja korespondencji to praca z materiałem dość nietrwałym, który nierzadko nie przetrwał w całości próby czasu. Usterki mechaniczne, woda, ogień, pleśnie - to wszystko zagraża papierowi i zapisanym na nim słowom. W przypadku listów Szukalskiego było podobnie, a przynajmniej tak się możemy domyślać, gdy dowiadujemy się, że czasami „list się «urywał»” (s. 43). Co to oznacza? Nie zachowała się dalsza część listu? Mamy do czynienia z uszkodzeniem papieru? Szukalski zaniechał dalszego pisania? Edytor tego nie wyjaśnia, wskazuje jedynie, że 
oznaczył takie miejsca wielokropkiem w nawiasie okrągłym. Problem w tym, że tak samo zrobił z fragmentami, przy których wystąpiły „trudności z odczytaniem” (s. 43). $\mathrm{W}$ efekcie nie wiadomo, czy list uległ uszkodzeniu, czy jakiś jego fragment jest nieczytelny.

Równie nieprecyzyjna jest się informacja: „Uzupełnieniem prezentowanych listów są ilustracje, w większości towarzyszące korespondencji, bądź ilustrujące poruszaną problematykę." (s. 43). I rzeczywiście - poszczególne części zbioru listów są oddzielane m.in. rysunkami autorstwa Szukalskiego lub fotografiami jego dzieł, bądź też portretami jego i innych osób, ale darmo szukać informacji, które były przesyłane razem z listami, a które pochodzą z innych źródeł. Zastrzeżenie to dotyczy także rysunków wplatanych w tekst (np. s. 169) — tu także nie wiadomo, czy rysunek był dołączony do listu, czy też nie.

Tyle z Noty edytorskiej się dowiadujemy. Brakuje w niej natomiast m.in. omówienia takich kwestii jak:

1. Sposób potraktowania wyróżnień, podkreśleń i skreśleń występujących w listach Szukalskiego.

2. Informacja na temat używanych skrótów, uzupełnianych, korygowanych lub nie (np. zapis n. p. (s. 110, 163), t. z. (s. 146), etc (bez kropki) (s. 153), T. V. (s. 259).

3. Informacja skąd pochodzi tytuł całości zbioru.

4. Informacja na temat motta zbioru (s. 5) i wiersza Wartczanom (s. 7) — skąd pochodzą, gdzie były drukowane?

5. Informacja czy szkice Coś niecoś o mnie (s. 45-50), Macimowa, czyli protong (s. 51-53) były już publikowane, a jeżeli tak, to gdzie? Jaka jest ich rola w książce? Czemu wybrano właśnie te, a nie inne?

6. Informacja na temat rysunków dołączanych do listów lub kreślonych na kartach listów. Na s. 238 reprodukowany jest list, w którym są widoczne rysunki. Czy są to rysunki autorstwa Szukalskiego, czy to papeteria? Jeżeli to szkice autora, to czy było ich więcej i czemu nie dowiadujemy się o nich przy każdym liście, w którym one się znajdują

7. Informacja dotycząca osobliwości zapisu i sposobu potraktowania tych zapisów: „co-to” (s. 48), „po-rozbiorowa” (s. 49), „okrągło-gładkie” (s. 50), ,zko-ordynował”, „obrazko-pismo”, ,przed-deluwialny”, „cztero-twarzy” (s. 58), „Świat-O-wid” (s. 59) i „Świat-Owid” (s. 65), „przed-Chrześcijańska” (s. 59), „z-użycie” (s. 60), „Je-Z-Us a”, ,pod-rozmów”, „bez-grzeszny” (s. 61), ,z-Chrześcijanienie” (s. 62), „nic-a-nic”, „coś-nie-coś” (s. 66), „zHowa-na”, „nie-gramatyczną” (s. 67), „za-lania” (s. 68), „to-hebrajskich” (s. 69), „nie-Katolicy” (s. 70), „bez-twarze” (s. 71), „między-planetarne”, „wszędzie-rozrzucone”, „bio-polityczne” (s. 81), „Sur-realizmy” (s. 83), „Sur-Realiści” (s. 84), „chlebo-jad” (s. 85), „prze-ważne” (s. 94), „u - racjonalizowana” (s. 96), „roz-członkowania”, „nie-polskie” (s. 110), z-użyłeś (s. 118) itd. Zaznaczyć należy, że to niewielki wycinek sformułowań, które wymagają komentarza. Tu wynotowano jedynie kilkanaście z pierwszej części zbioru, a trzeba podkreślić, że występują one w całej kolekcji listów.

8. Informacja dotycząca osobliwości posługiwania się wielką literą - Nauka, Wiara, Kultura, Koncepcja, Polot, Racja, Imperium, Dobro, Żądza, Moralność, Ideologia, Niewola, Nazizm, Kościół, Człowiek, Kult, Naród, Biografia, Sztuka, Cywilizacja, Społeczeństwo, Twórczość, Modernizm, Ilustracje, Monogra- 
fia, itp. (tu, podobnie jak wcześniej, wynotowano zaledwie niewielką część słów tak zapisywanych).

9. Informacja o działaniach słowotwórczych Szukalskiego - macimowa, zermatyzm, czołownik, twórcownia, itd.

10. Pełna, kompletna informacja o innych osobliwościach języka Szukalskiego, a także o stosowaniu przez niego, zaledwie wspomnianych w Nocie, archaizmów i regionalizmów; zob. m.in.: manja (s. 113), stałsze (s. 115), boć (s. 130), pierwej (s. 133), nadeszlę, skorze (s. 138), przeć (s. 139), mię (s. 142, 171), tem (s. 156), pędnia (s. 159), wsiowy (s. 246, 261), New Yorska (s. 488).

11. Informacja o zamieszczanych na końcu bloków listów z danego roku (także Wstęu, s. 39, dwóch przywołanych wcześniej szkiców — s. 50 i 53) ozdobnikach graficznych przedstawiających rogate serce - czy to twór Szukalskiego, czy np. autora okładki?

Książka została wydana $\mathrm{z}$ dużym staraniem i pietyzmem dotyczącym szaty zewnętrznej (twarda oprawa, dobrej jakości papier), ale z mniejszą starannością redakcyjną i korektorską. Zdarzają się w niej liczne błędy gramatyczne (np. s. 13, 19, 26), dodatkowo często w aparacie krytycznym pojawiają się usterki stylistyczne (można się jedynie domyślać, co miał autor na myśli pisząc m.in. „całkowita datacja” (s. 43); „,poglądy i prądy ideowe, dominujące nad Europą" (s. 16); objaśnienie do zdania: „Wszystko zostało zatrzymane bo Etiopia jest teraz osaczona i kontrolowana, a Saudia w niebezpieczeństwie” (s. 529), które brzmi: „Etiopia w tym czasie ogarnięta była wojną domową, konfliktem z Somailą i wpływami sowieckimi” (przypis nr 668)). Osobną kwestią jest interpunkcja. Liczba błędów występujących w listach Szukalskiego poraża. Nie było żadnych powodów, aby ten stan rzeczy zachować — sam autor był świadom swoich niedostatków w zakresie posługiwania się językiem pisanym, a listy mają charakter informacyjny, więc z powodzeniem można było poprawić, ujednolicić w nich interpunkcję.

Błędów i przewinień edycyjno-edytorskich jest tu dużo więcej. Ograniczmy się do wymienienia tych, które najbardziej rzucają się w oczy przy choćby pobieżnym przejrzeniu książki.

Dość często brakuje wyróżnienia cytatów w cytacie (np. s. 12, 13, 16, 26, 93), otwierającego cudzysłowu (s. 25, 131), zamykającego cudzysłowu (s. 46, 166, 173), zamykającego nawiasu (s. 82, 143, 157), oznaczenia cytatu, choć opatrzono go przypisem (s. 17).

Równie wiele błędów dotyczy stosowania dywizów i półpauz, które inaczej są używane w tekście głównym, inaczej w przypisach, a niekonsekwentnie w obu przypadkach (por. np. przypisy nr 236; 276-277; 362-363; 499-500). Czasami w książce można natrafić na rozwiązania zupełnie niezrozumiałe, jak choćby trzy umieszczone obok siebie dywizy w połowie s. 327.

Spacje także pojawiają się dość dowolnie, w tym m.in. przed dywizami, przecinkami, kropkami, nawiasami zamykającymi (np. s. 51, 158, 168, 175, 197, 615, 682); lub przeciwnie, brakuje ich w miejscach, w których powinny się pojawić (s. 409, 494, 506, 529, 597).

Niekiedy wypowiedź się urywa, zakończona jest średnikiem [!] (s. 175), pojawiają się nadmiarowe puste linie (s. 484), czasami na końcu zdania brakuje kropki (s. 167), wstawiane są dwa nawiasy otwierające i jeden zamykający (s. 766) lub tyko jeden zamykający (przypis nr 474, s. 347).

Niejednolicie potraktowano sprawę rozwijania słów zapisanych w wersjach skróconych. $\mathrm{Z}$ jednej strony zastosowano uzupełnienia w nawiasach kwadratowych $\mathrm{z}$ za- 
chowaniem kropki i otrzymujemy m.in. zapis: Akad.[emii] Um.[iejętności] (s. 126) i Funduszu Sz.[ukalskiego] (s. 132; por. także np. s. 89, 162, 172, 193). A z drugiej strony często słowa zapisane w wersjach skróconych (niekiedy te same, które w innych miejscach są uzupełnione) nie otrzymują rozwinięcia (np. s. 89, 107, 145, 154, 193).

Równie duża dowolność panuje w zakresie zapisu tytułów przywoływanych dzieł. W przypisach na s. 279 (przypis nr 419 i 420) tytuły dzieł nie zostały wyróżnione w żaden sposób (kursywa, cudzysłów), ale np. na s. 85 (przypisy nr 155 i 156), s. 131 (przypisy nr 212 i 214), s. 205 (przypisy nr 320 i 322), s. 270 (przypis nr 406) tytuły dzieł zostały ujęte w cudzysłów. Podobnie w przypisie na s. 110 tytuł szkicu zgubił cudzysłów zamykający, a praca zbiorowa otwierający (dodam, że tytuł pracy zbiorowej przytoczony z błędem). Z kolei np. w przypisach nr 118 (s. 58), 148 (s. 75) i 325 (s. 206) tytuły dzieł zostały dla odmiany zapisane kursywą.

Niejednolity jest także zapis tytułów czasopism. Na przykład londyński tygodnik „Wiadomości” czasami jest zapisywany w cudzysłowie (s. 18, przypis nr 18; s. 97, przypis nr 169; s. 422, przypis nr 550), a czasami bez cudzysłowu (s. 285, przypis nr 426 - tu także „Wiadomości Literackie” bez cudzysłowu).

Różnorodny jest zapis objaśnień słów i zwrotów w obcych językach. Np. na s. 509 przypis nr 644 wygląda następująco: „ex Officio (łac.) — z urzędu, z obowiązku”, na s. 568 przypis nr 700 ma postać: „łac- bez końca” (brak kropki i spacji przed dywizem, który powinien być zastąpiony półpauzą), a na s. 261 przypis nr 388 głosi: „franc.sławny malarz z Krzeszowic" (brak spacji przed dywizem, który powinien być zastąpiony półpauzą). Nie ma tu żadnej konsekwencji — na s. 70 przypis nr 143 zaczyna się małą literą, a objaśnienie jest przytoczone w cudzysłowie: „ros. — «za zgodą cenzury»”, na s. 211 przypis nr 328 wygląda tak: ,(z czeskiego) — odpowiedni”, na s. 375 przypis nr 493 ma postać: ,,ang. - prosto” (por. m.in. s. 275, 279, 392), a na s. 293 przypis nr 433 głosi: „Solstice (ang.) — przesilenie dnia z nocą”. W tym kontekście nie dziwi, że nie wszystkie zwroty obcojęzyczne zostały objaśnione (zob. np. double talk, s. 306).

Z innych błędów należy odnotować:

1. Brak konsekwencji w oznaczaniu w przypisach okresów rozdzielonych narodzinami Chrystusa. Obok oznaczenia „,p. Ch.” (s. 245) pojawia się „p.n.e.” (s. 243, 325, 450), a obok „po Ch.” (s. 818) zapis „n.e.” (s. 94). Tu trzeba dodać, że te pierwsze formy powinniśmy zapisywać „,przed Chr.” i ,po Chr.”.

2. Brak konsekwencji w zapisie dat rocznych określających lata życia danej osoby lub np. okres działalności jakiejś instytucji. Większość doczekała się zapisu pełnych lat (np. 1881-1975), jednak są też takie, które zostały zapisane w wersji skróconej (np. w przypisie nr 317 na s. 201: „1959-61”, w przypisie nr 705 na s. 573: „1933-99”).

3. Brak konsekwencji w edycji przypisów. Na s. 321 są dwa przypisy. Pierwszy z nich (nr 450) zaczyna się tak: „Apollo — w mitologii grackiej syn Zeusa [...]”, a drugi (nr 451) tak: „Tantal, w mitologii greckiej syn Zeusa [...]”. Dowolność w użyciu myślników i przecinków oddzielających definiowane hasło od jego opisu to w tych przypisach ,norma”.

4. Niekonsekwentny i błędny zapis skrótów: „m.in.” jest zapisywane ze spacją (s. 65, 85, 151, 154), a czasem bez spacji (s. 323, 421), choć i tak najbardziej zaskakująco wygląda w przypisie nr 202 (s. 120), w którym skrót został podzielony między dwie linijki.

5. Brak konsekwencji w zapisie daty w przypisach - czasami po dacie pojawia się słowo „roku” (np. s. 155, 366), czasami skrót „r.” (np. s. 104, 131, 138, 
141, 149), a czasami tylko data (np. s. 100, 131, 155, 167). To samo dotyczy zapisu „wieku” (s. 99, 130, 225, 376) i „w.” (s. 178, 551, 766), przy czy ten skrót jest czasami zapisywany bez kropki (zob. przypis nr 285, s. 181).

Część osób przywoływanych w listach nie doczekała się przypisów, ale są i takie, które otrzymały dwa przypisy w różnym brzmieniu — np. Konfucjusz (przypis nr 369 s. 245 i przypis nr 646 s. 510; por. także dwa przypisy wyjaśniające, czym były „Wiadomości” — s. 97 i 285). Niektóre przypisy niewiele wyjaśniają — np. na s. 552 w liście Szukalskiego pojawia się „Lolek” opatrzony przypisem nr 689: „Jan Paweł II”, na s. 693 wspomniany jest „Szef”, który w przypisie nr 769 jest rozszyfrowany jako „Papież”, a na s. 699 pojawia się „Młocarz”, do którego przypis 776 jest analogiczny treściowo do przypisu nr 689.

Zresztą merytorycznej zawartości przypisów można by poświęcić osobne omówienie. Przytoczmy (w całości!) kilka z nich: „Karol Wojtyła (1920-2005) — arcybiskup metropolita krakowski, kardynał, od 1978 r. papież Jan Paweł II” (s. 548), „Marian Wacław Szyszko-Bohusz (1901-1995) — polski malarz ekspresjonista, krytyk sztuki i publicysta” (s. 285); „,Wojciech Kossak (1856-1942) - malarz, tworzył obrazy głównie o tematyce historycznej i batalistycznej” (s. 301), „Lech Wałęsa, przywódca strajku w Stoczni Gdańskiej w sierpniu 1980 r., przywódca NSZZ Solidarność, prezydent Polski” (s. 653).

Niby wszystko się zgadza, ale czy czytelnik na postawie tych przypisów będzie potrafił oszacować, o jakiego formatu postaciach tu mowa. Potem pojawiają się m.in. przypisy: „Michał Chmielowiec (1918-1974) — pisarz, krytyk literacki, redaktor, poeta i prozaik, prowadził emigracyjne «Wiadomości» londyńskie” (s. 422 — bez wspomnienia o Mieczysławie Grydzewskim, założycielu i wieloletnim redaktorze pisma); „Maria Gliwa (1915-2009) — żołnierka AK, więźniarka KL Ravensbruck [!], opiekunka dorobku męża" (s. 560 - czy bycie żoną wydawcy to najważniejsza rola?). Ale to $\mathrm{i}$ tak nic $\mathrm{w}$ porównaniu $\mathrm{z}$ takimi przykładami (cytowane in extenso): „Wanda imię zapisane po raz pierwszy przez Wincentego Kadłubka, według którego była to legendarna władczyni Krakowa, córki [!] Kraka” (s. 627), „Grog — rum lub inny silny trunek, rozcieńczony wodą; zawierać może sok z cytrusów, cynamon, gorącą wodę lub cukier dla poprawy smaku” (s. 279), „ «National Geographic» — czasopismo wydawane od 1888 r. przez National Geographic Society. Ukazuje się 12 razy w r.” (s. 790), „Konfederacja Targowicka — synonim zdrady narodowej” (s. 408), „Władysław Gomułka (1905-1982) — polityk komunistyczny, I sekretarz KC PPR, I sekretarz KC PZPR” (s. 454), objaśnienie słowa „buzerant”: „Z czeskiego — pedał, ciota” (s. 396), objaśnienie słowa „gazolina”: „Chodzi o gas oil — olej napędowy” (s. 464), „«Orbis» — biuro podróży” (s. 483), objaśnienie do zdania: „Ty wspomniałeś Lameńskiego, który [...] był wykształcony przez Polskiego [...] profesora w prowincjonalnym Lublinie [...]” (s. 537): ,prof. Andrzeja Ryszkiewicza” (przypis nr 678).

Układ przypisów to zresztą osobna sprawa. Na s. 618 jest mowa o stanie wojennym w Polsce, ale przypis wyjaśniający, czym on był znajduje się na s. 653. Na s. 116 mowa o „Szpilkach”, ale przypis wyjaśniający co to za czasopismo pojawia się na s. 131. Aleksander Janta-Połczyński pojawia się na s. 14 (przywołany tylko z nazwiska, bez imienia), następnie na s. 18 (z imieniem), ale przypisem został opatrzony dopiero na s. 97. Władysław Jarocki pojawia się na s. 21 i 273 bez przypisu, a zyskuje go dopiero na s. 386. Wymieniany na s. 34, 116, 124, 125 Roman Romanowicz otrzymuje przypis dopiero na s. 131 (dodajmy, że przypis jest obarczony błędem powtórzeniowym: „Roman Romanowicz (1931-2016) — architekt, siostrzeniec Szukalskiego, 
znawca i propagator jego twórczości, siostrzeniec Szukalskiego [!]”. Z kolei Barbara Tyszkiewiczowa (przypis na s. 124) pojawia się na s. 131 z adnotacją „NN". Za to Zbigniew Pronaszko wymieniony na s. 56 (z przypisem) na s. 114 zmienia imię na Zygmunt, aby w indeksie nazwisk stać się znowu Zbigniewem.

Myliłby się ten czytelnik, który uzna, że wszystkie postaci wymieniane przez Szukalskiego w listach zostały opatrzone wyjaśniającymi przypisami. Nie otrzymali ich m.in. dziadek Szukalskiego - Kasper (s. 45 i następne - tu dodatkowo warto zapytać, dlaczego w indeksie zapisany został jako Kacper?), jego ojciec - Dionizy (s. 10 i następne), stryj Kalikst i kuzynka Jadwiga Dekańska (s. 320), pradziadek Stanisław (s. 46), pani Przeździecka (s. 112 i następne), członek PZPR, organizator pielgrzymek — Milejski (s. 189), Straight (s. 357), Duszyńska (s. 563), artysta plastyk Tymon Niesiołowski (s. 10). Co więcej przypisami nie zostały opatrzone także m.in. tygodnik „Warsaw” (s. 195), londyński „Tydzień Polski” (s. 568), cytat z artykułu z „Rzeczpospolitej” (s. 281), artykuł Aleksandra Małachowskiego z 15 numeru „Kultury” z 1978 roku (s. 507). Na s. 341 w liście Szukalskiego jest mowa o „Polsce II-iej”, co opatrzone zostało przypisem „II Rzeczpospolita”. Pomijając już fakt, że ten przypis niczego nie wyjaśnia, zaskakujące jest to, że gdy w kolejnej linii (s. 342) czytamy o „Polsce III-iej”, to ona przypisu już nie otrzymała. Choć przypisami opatrzono Apolla, Pegaza, Tantala, to już np. nie Prometeusza (s. 554). W przypisie nr 474 na s. 347 mowa o Wielkiej Tamie Asuańskiej; czemu nie ma zatem przypisu do katedry Notre Dame (s. 534)? Na s. 601 jest przypis do Muzeum J. Paula Getty’ego; czemu nie ma zatem przypisu do kościoła św. Katarzyny (s. 249)?

Opatrzenia osobnymi komentarzami wymagałby szereg fragmentów niejasnych bez poznania ich kontekstu. Gdy Szukalski pisze: „Jaka to szkoda, że Kardynał Wyszyński nie skorzystał z tak rzadkiej okazji, jak otrucie Papieża, i proklamował się Papieżem!" (s. 542), to szacunek dla autora nie może zwalniać edytora z opatrzenia tekstu choćby krótkim przypisem wyjaśniającym. Podobnie czytelnik gubi się w domysłach czytając o operacji przepukliny „w klinice Uniwersytetu Bliskiego” (s. 311), a także w tych miejscach, w których Szukalski rozwodzi się na temat Księżyca, panujących na nim warunków i niemożności wylądowania na srebrnym globie.

Zastrzeżenia budzi również indeks nazwisk. Odnajdujemy w nim bowiem takie postaci, jak: bóg Ra, Ezop, biblijnych Tobiasza i Lameka, Noego i Sarę, Dawida i Goliata, Piastów i Shang (dynastie), postaci pojawiające się jako patroni miejsc (św. Katarzyna jako patronka świątyni, św. Leonard jako patron krypty wawelskiej).

Powyższe uwagi odnoszą się do najważniejszych błędów i potknięć, jakie dostrzeżono w pracy. Podane przykłady nie stanowią listy wyczerpującej, tę powinien - na etapie przygotowania do druku - sporządzić redaktor lub korektor tomu (niestety na karcie redakcyjnej ani jeden, ani drugi nie zostali wymienieni). Pozostaje wyrazić jedynie żal, że - skądinąd niezwykle zajmujący zbiór korespondencji ukazał się w tak źle przygotowanej edycji. Traci na tym nie tylko czytelnik, który przymykając oczy na usterki, zechce się z tym opasłym tomem zapoznać, ale przede wszystkim jego autor i zarazem bohater - Stanisław Szukalski. Artysta wielkiego formatu, geniusz zmagający się sobą i światem...

Rafał Moczkodan (Uniwersytet Mikołaja Kopernika w Toruniu)

ORCID: 0000-0003-1287-2888 